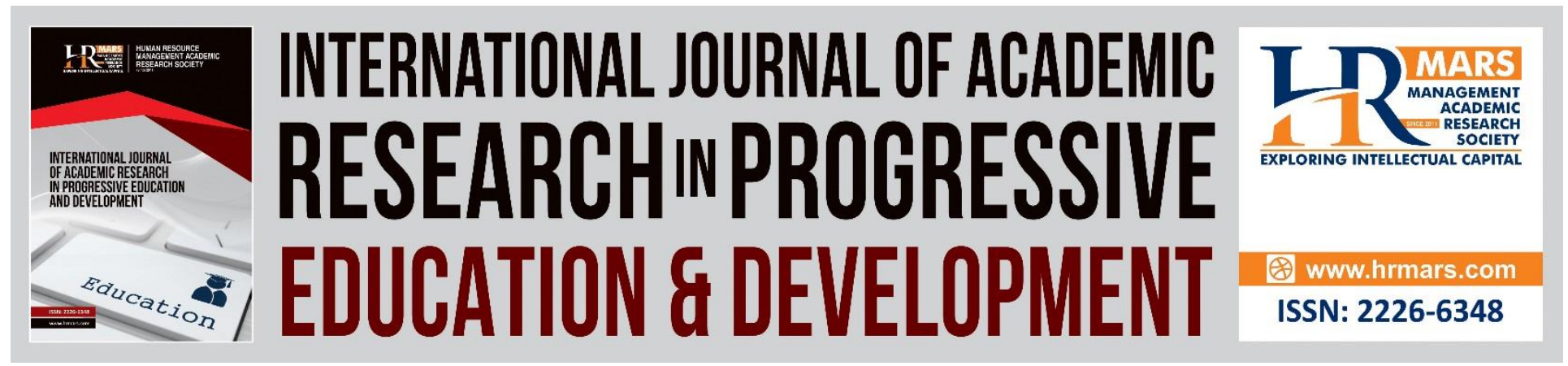

\title{
Discipline and Academic Performance (A Study of Selected Secondary Schools in Lagos, Nigeria)
}

Ehiane, O. Stanley

To Link this Article: http://dx.doi.org/10.6007/IJARPED/v3-i1/758

DOI: $10.6007 /$ IJARPED/v3-i1/758

Received: 12 January 2014, Revised: 19 February 2014, Accepted: 14 March 2014

Published Online: 27 March 2014

In-Text Citation: (Ehiane, 2014)

To Cite this Article: Ehiane, O. S. (2014). Discipline and Academic Performance (A Study of Selected Secondary Schools in Lagos, Nigeria). International Journal of Academic Research in Progressive Education and Development, 3(1), 193-207.

Copyright: (C) 2014 The Author(s)

Published by Human Resource Management Academic Research Society (www.hrmars.com)

This article is published under the Creative Commons Attribution (CC BY 4.0) license. Anyone may reproduce, distribute, translate and create derivative works of this article (for both commercial and non-commercial purposes), subject to full attribution to the original publication and authors. The full terms of this license may be seen

at: http://creativecommons.org/licences/by/4.0/legalcode

Vol. 3(1) 2014, Pg. 193 - 207

http://hrmars.com/index.php/pages/detail/IJARPED

JOURNAL HOMEPAGE

Full Terms \& Conditions of access and use can be found at http://hrmars.com/index.php/pages/detail/publication-ethics 


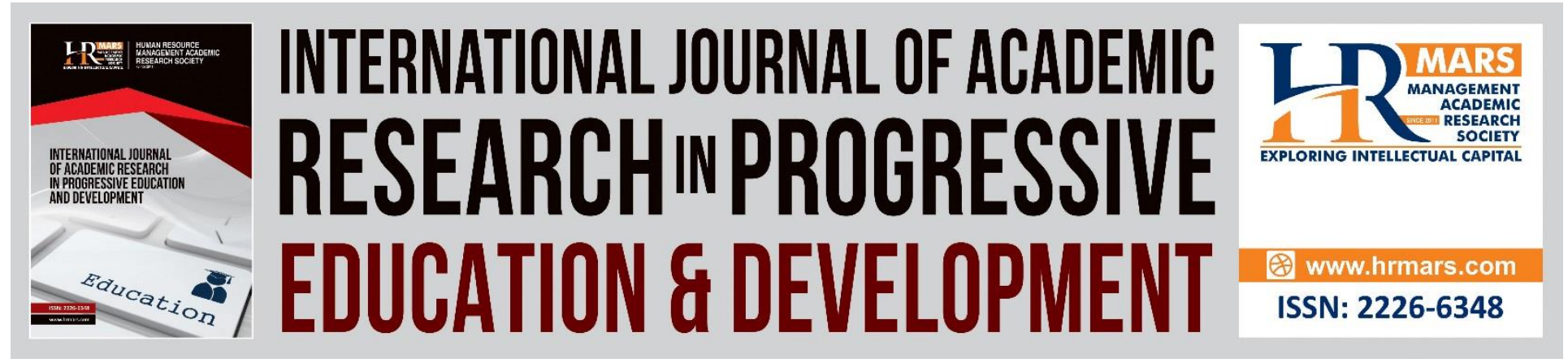

\title{
Discipline and Academic Performance (A Study of Selected Secondary Schools in Lagos, Nigeria)
}

\author{
Ehiane, O. Stanley \\ Lagos State Polytechnic, (SPTSA), Ikorodu, Mainland Annex, Lagos, P. O box 2090, Ikeja, Lagos, \\ Nigeria \\ Email: stanleyehiane@yahoo.com
}

\begin{abstract}
Disciplines and academic performances are the core of our today's education. Some scholars have attributed poor performance of students in academic to high level of indiscipline among students while others disagreed. Nevertheless, it becomes imperative in recent times that many schools have traded away discipline and as a result led to poor academic performance of students. This study was carried out to establish the relationships between schools discipline and students' academic performance. The study employed cross sectional research survey design in which questionnaire was the main instrument of data collection in addition to interview guide and document review. Simple percentage and chi-square statistical method were used to analyze the data. However, the findings of the study clearly showed that effective school discipline should be encouraged in controlling students' behaviour thus affects students' general academic performance.
\end{abstract}

Keywords: School Discipline, Performance, Academics, Expulsion

\section{Introduction}

Scholars in recent times have written more on indiscipline among pupils and its effects on learning outcome and their progress in schools. Some scholars suggest that disciplinary policies simply do not have defferent effects (Verdugo and Glenn, 2002; Chen, 2008; Schoonover, 2009). Other asserts that suspensions do not prevent students' future misbehaviour (Nichols, 2004). If school is effectively disciplined, the academic performance on the part of student and teacher will be highly rated. Gawe et al (2001:190) express cooperative learning if academic performance is to be achieved among students.

However, apart from the fact that effective discipline helps in the achievement of goals, expectation and responsibility in students (Dunham, 1984:66). Discipline creates a good image of the school and prepares learners for the future. Disruptive behaviour amongst learners is eliminated if there is good discipline at school. The implementation of effective discipline at 
school is a key for the student in the journey to adulthood. Parents often have no choice but to enroll their children in a school with good discipline, which often leads to better academic performances.

In our secondary schools today, learners are habitual late comers; this is contrary to the school rules and regulations. They leave school premises without permission; do not bring their books to school; refuse to do their homework; reject any kind of authority and resist any disciplinary measures taken against them. Teachers on the other hand, are always absent from school; present ill-prepared lessons; fail to exercise discipline in the classroom and lack a professional work ethic. According to Bieketty (2004) he opine that lack of discipline and respect among teachers cause a severe barrier to effective teaching and learning in the classroom. Discipline have been underestimated by over actualizing freedom and rights, an understatement of responsibilities and obligations, marginalisation of the authority of the head teacher, poor role models by some teachers, lack of punctuality, abscondment from classes by both learners and teachers and the unionist attitude of some teachers.

The head teachers as school managers need to have an effective leadership style so as to acquaint them with the challenges of disciplining learners. Everard and Morris (1996:14) explain leadership styles as autocratic, paternalistic, consultative as well as democratic. These styles can play a major role in the implementation of discipline.

\section{Statement of Problem}

School administrators continue with maintaining conducive learning environment by ensuring the operation of discipline in school for academic performance. However, the researcher discovered in recent times that students' poor academic performance is attributed to school's administrator, teacher and student indiscipline. Indiscipline in schools can manifest itself in students' violent behaviour, poor disciplinary style, ineffectiveness and inefficiency of teacher, poor time management, and ineffective code of conduct and so on. These acts of indiscipline engage by the schools disrupt learning and have direct impact on students' achievement.

\section{Research Question}

This study identifies some research questions which are the main objectives of this work. The research questions are:

- Could management of school discipline affect students' academic performance?

- Would the incident of observance of time management affect student performance?

- Are rule and regulation in school affect students' academic performance?

- Would administrations of punishment in school improve students' academic performance

\section{Research Hypothesis}

In answering the research questions, the following hypotheses were formulated and tested.

\section{Hypothesis 1}

HO: $\quad$ There is no Significant Relationship Between School Discipline and Students' Academic Performance. 
Vol. 3, No. 1, 2013, E-ISSN: 2226-6348 @ 2013 HRMARS

Hi: There is a significant relationship between school discipline and student academic performance.

\section{Hypothesis 2}

Hi: $\quad$ The administration of punishment enhances academic performance.

Ho: The administration of punishment does not enhance academic performance.

\section{Literature Review}

Time management skill between students and teachers has proved to have direct correlation with performance level. However, the students who perceive to have good time management are those that have the desire to achieve, result in higher level of academic performance. However, the issue of punctuality needs to be observed not only by students but also teachers, head teachers and non-teaching staff in an educational institution, as part of the efforts toward academic excellence. Mafabi, et al (1993), opine that, success can only be achieved in school when teachers shows good example of time management. Though the practice in most of the secondary schools is that school activities seems not to respect the designed time table. There is a need therefore to establish compliance on the part of the stokeholders in the management of school to ensure good " academic performance. Docking (2000) argues that, a law abiding student is the one expected to arrive on time for lectures and wait for the teacher, while law abiding teacher is expected to respect all the time allocated to him or her on the timetable. Kelly, (2004) argues that efficient use of time on the part of the students and school administrator directly associated with increased academic performance. Brint, and Cantwell (2006) also concur and further explain that extra time study has a strong influence on academic attainment. Eilam and Aharon (2003) stress that time management can be view as a way of monitoring and regulating oneself with regards to the performance of multiple tasks within a certain time period. Therefore, to improve academic performance, both the student and staff self attitude and participation is required as a principle of time management practice.

The use of punishment in schools is to instil discipline and is melted on student who violates the agreed rules and regulations in schools. It is administered to bring about a desirable change in behaviour and therefore improving school discipline, if commensurate with the offense committed (Okumbe, 1998). However, what we experience in recent times is that there are situation where a student who commits an offence, can easily go unpunished. Nevertheless, in most secondary schools some forms of punishments are unfair and undeserved like corporal punishment in schools involving severe canning, suspension, expulsion, branding and mutilation of students (Encarta, 2009). Docking (2000) in his opinion on application of punishments in schools in the United Kingdom he observed that, some punishments are appropriate and constructive while others are not desirable, baseless and instead intended to instil fear. This idea is also in agreement with canter (2000) who argues that although discipline remains one of the most common problems for teachers, some punishments such as corporal punishments should not be used because no evidence suggests that they have produced better results academically, morally or that it improves school discipline. According to Mafabi, et al (1993) punishments are expected to enforce compliance when students are under the care of teachers. This opinion is also shared by Cotton, et al (2000), who said that punishments in a school system are expected 
to teach students the relationship between their behaviours and the outcome or accountability for their mistakes. Creswel (2003), also argues that with a well-behaved class, teaching could be among the most wonderful jobs in the world. However what really occurs on the ground is that unwanted behaviours are on the increase despite the presence of these punishments. Teachers are worried about the aggression being directed to them by both students and their parents. This has resulted into some students being expelled, others suspended, forced to do hard labour at school, chased out of classes all of which seem to affect their academic performance. They further argue that some forms of punishments like corporal punishment could lead to physical injury if teachers are not careful in its administration. This would lead to absence from schools and consequently reducing the academic performance of the injured students Baumard (1999) shared the same opinion but argued that punishment is a means of controlling disruptive behaviour. He further stated that if punishment is the logical result of misconduct, the student is likely to accept it without resentment. Teachers need always realize the appropriateness of punishment before initiating it. Cotton, et al (2000) also contends that uniform punishment can be an effective way of controlling students" behaviour if students, teachers and school administrators know and understand that punishment are firm, fair and consistent.

Ideally, schools set discipline for the proper governing of the various lifestyles of students i:e the dos and don'ts. Okumbe (1998), opines that regulations on the other hand are authoritative disciplines with a course of law intended to promote discipline in school. Hernandez and seem, (2004), argue that the operation of schools' is directly influenced by the way the schools' administered students disruptive behaviour. They further explained that the parameters for students' behaviour and academic expectations must be clearly stated to students. If the school administrator fails to clearly established rules and consequences are ambiguous and incidents of students' disruptive behaviour will further affect academic performance. Jones et al (2002), also concur with Hernandez and Seem (2004), he argues that effective schools demonstrate sound inclusive practices which includes emphasizing school discipline, collaborative leadership and their good practice. The school discipline therefore prescribes the standard of behaviour expected of the teachers and the students. According to Matsoga (2003) in his study, he discovers the wide spread violence and misbehaviour that existed in many secondary schools. This lack of discipline which interferes with the teaching and learning process manifested itself in various ways including bullying, lateness, vandalism, alcohol consumption and substance abuse, truancy and inability or unwillingness to do class work at home. Schools disciplines are among the strategies designed to instil good conduct of students, this implies self-control, good behaviour and obedience to school authority (Adams, 2003). However, on admission students are given prospectus, which spell out some of these rules specify in most cases what students should do and what they should not do. Kabandize (2001) observes that disciplines are enforced through prefects" bodies and councils, disciplinary committees, teachers and involvement of parents. Cotton, et al (2000) also argue that the best results could be obtained through vigilantly reminding students about disciplines in school and monitoring their compliance with them. Adeyemo (1985), in his study on the level of discipline in secondary schools in Nigeria, he established that there is wide spread violation of school rules and regulations which was capable of obstructing the smooth functioning of the school system and thereby affect pupils performance. 


\section{Material and Method}

This study examines the effects of school discipline on academic performance in Nigerian secondary schools and a structured questionnaire was used as the main instrument of data gathering. However, ten secondary schools were selected for the purpose of this study on the basis of: ownership, religion, old, new and gender while sample technique was applied.

The total number of questionnaires distributed was 400 in all the ten schools and 380 were returned to the researcher representing $95 \%$ of the total questionnaires distributed. Meanwhile, all the data collected through the questionnaire were analyzed, summarised and interpreted using simple percentage and Chi-square method to measure inconsistency between the observed and expected frequencies and to prove the level of significance in testing the stated hypotheses. The responses from the questionnaires were measured with likert scale: a five-point scale namely, strongly agrees, agree, neural, disagree and strongly disagree. This is used to register the extent of agreement or disagreement with a particular statement of an attitude, belief or judgement. In addition to, the questionnaire the researcher also conducted interviews with some of the administrative staff of the schools $\mathrm{i}$ : e the Vice principal and the principal to further prove the effects of school discipline on students' academic performance. However, other secondary sources of data consulted in course of this study include academic journals, research work and textbooks.

\section{Result and Discussion}

The responses obtained from the distributed questionnaires are presented and analyzed below.

Table 1: Gender

\section{Source: Field survey, 2014}

\begin{tabular}{|l|l|l|}
\hline Sex & Respondent & Percentage \\
\hline Eemale & 220 & $57.8 \%$ \\
\hline Male & 160 & $42.2 \%$ \\
\hline Total & $\mathbf{3 8 0}$ & $\mathbf{1 0 0 \%}$ \\
\hline
\end{tabular}

Table 1 shows that 220 or $57.8 \%$ of the respondents were females while 160 or $42.2 \%$ were males. This revealed that more of the respondents were females. See figure 1 below for a graphic picture.

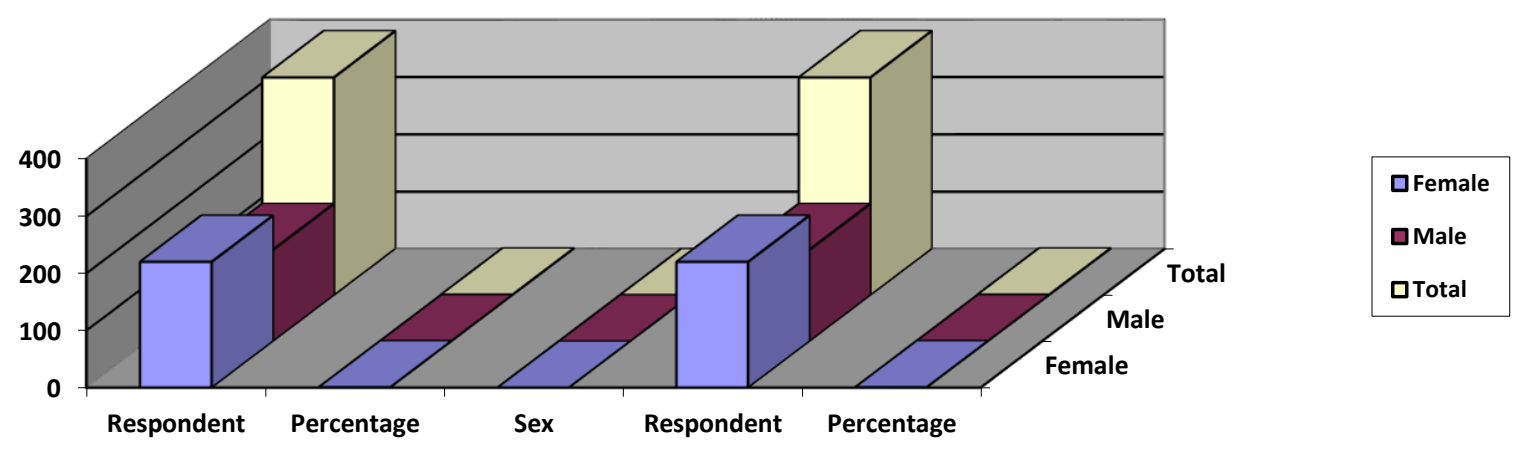


INTERNATIONAL JOURNAL OF ACADEMIC RESEARCH IN PROGRESSIVE EDUCATION AND DEVELOPMENT

Vol. 3, No. 1, 2013, E-ISSN: $2226-6348$ @ 2013 HRMARS

Table 2: Respondents Age

\section{Source: Field survey, 2014}

\begin{tabular}{|l|l|l|}
\hline Age & Respondent & Percentage \\
\hline $10-13$ years & 180 & $47.4 \%$ \\
\hline $14-17$ years & 200 & $52.6 \%$ \\
\hline $\begin{array}{l}18 \text { and } \\
\text { above }\end{array}$ & & \\
\hline Total & $\mathbf{3 8 0}$ & $\mathbf{1 0 0 \%}$ \\
\hline
\end{tabular}

Table 2 depict that 180 or $47.4 \%$ of the respondents were between the ages of $10-13$ years while 200 or $52.6 \%$ of the respondent were between the ages of $14-17$ years. Obviously, this revealed that majority of the respondents were in above 13 years of age. See figure 2 below for a graphic picture.

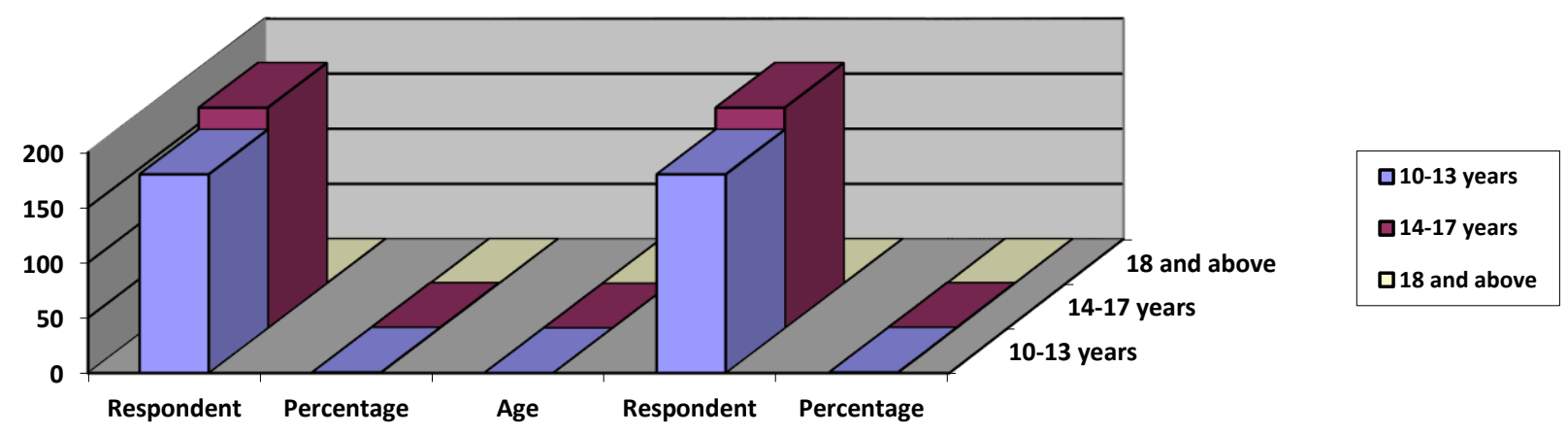

Table 3: student status

\begin{tabular}{|l|l|l|}
\hline Class & Respondent & Percentage \\
\hline Junior class & 150 & $39.5 \%$ \\
\hline Senior class & 230 & $60.5 \%$ \\
\hline Total & $\mathbf{3 8 0}$ & $\mathbf{1 0 0 \%}$ \\
\hline
\end{tabular}

\section{Sources: Field survey 2014}

Table 3 shows that 150 or $39.5 \%$ of the respondents were in junior class while 230 or $60.5 \%$ were in the senior class. Consequently, it revealed that most of the respondents were in senior class. See figure 3 below for a graphic picture. 


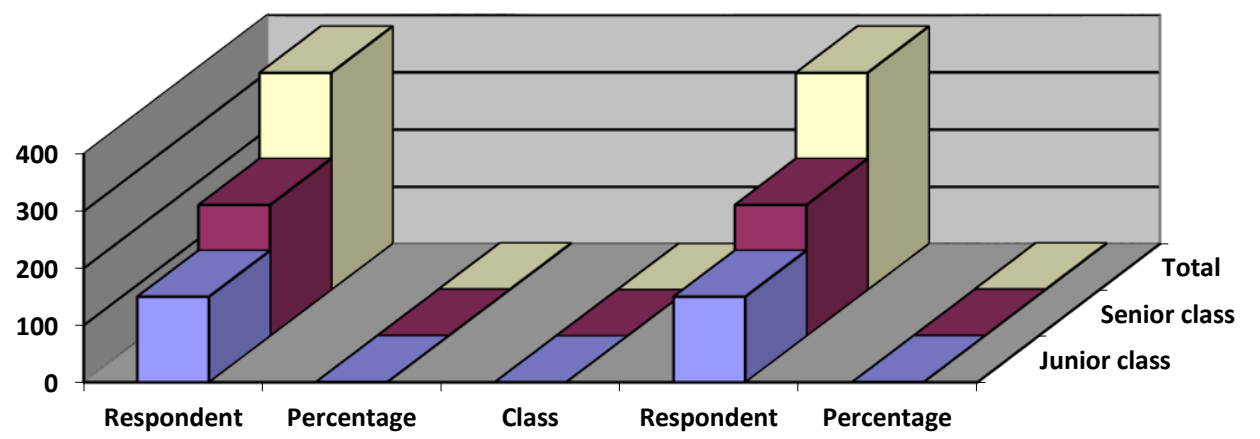

Table 4: Management of School Discipline Has Impact on Students' Academic Performance.

\begin{tabular}{|l|l|l|}
\hline Scale & Respondent & Percentage \\
\hline Strongly Agree & 280 & $73.7 \%$ \\
\hline Agree & 74 & $19.5 \%$ \\
\hline Neutral & 6 & $1.6 \%$ \\
\hline Disagree & 12 & $3.2 \%$ \\
\hline $\begin{array}{l}\text { Strongly } \\
\text { Disagree }\end{array}$ & 8 & $2.1 \%$ \\
\hline Total & $\mathbf{3 8 0}$ & $\mathbf{1 0 0 \%}$ \\
\hline
\end{tabular}

\section{Source: Field survey 2014}

Table 4 shows that 280 or $73.7 \%$ of the respondents strongly agree, while 74 or $19.5 \%$ of the respondents are of the similar views; 6 or $1.6 \%$ were neutral; 12 or $3.2 \%$ disagree and 9 or $2.1 \%$ strongly disagree. Obviously, majority of the respondents believed that management of school discipline has impact on the students' academic performance. See figure 4 below for a graphic picture of this result.

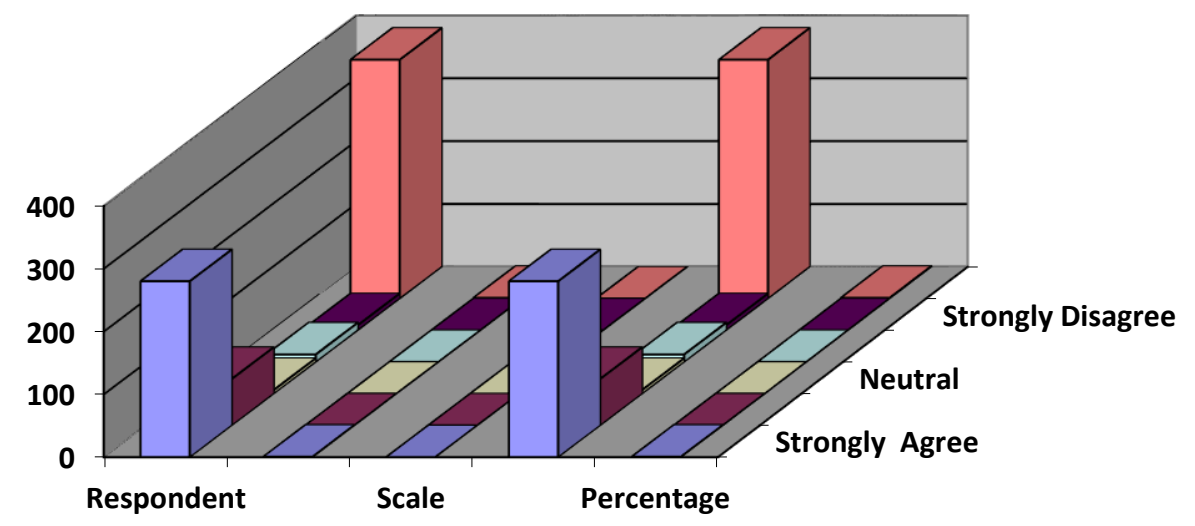

$\square$ Strongly Agree
$\square$ Agree
$\square$ Neutral
$\square$ Disagree
$\square$ Strongly Disagree
$\square$ Total
Respondent
Percentage 
Vol. 3, No. 1, 2013, E-ISSN: $2226-6348$ @ 2013 HRMARS

Table 5: Observance of time management affects student performance

Source: Field survey 2014

\begin{tabular}{|l|l|l|}
\hline Scale & Respondent & Percentage \\
\hline Strongly agree & 280 & $73.7 \%$ \\
\hline Agree & 100 & $26.3 \%$ \\
\hline Neutral & - & - \\
\hline Disagree & - & - \\
\hline $\begin{array}{l}\text { Strongly } \\
\text { Disagree }\end{array}$ & - & - \\
\hline Total & $\mathbf{3 8 0}$ & $\mathbf{1 0 0 \%}$ \\
\hline
\end{tabular}

From the table 5, 280 or $73.7 \%$ of the respondents strongly agree that the observance of time management affect students' academic performance while 100 or $26.3 \%$ of the respondents agree. See figure 5 below for a graphic picture of this result.

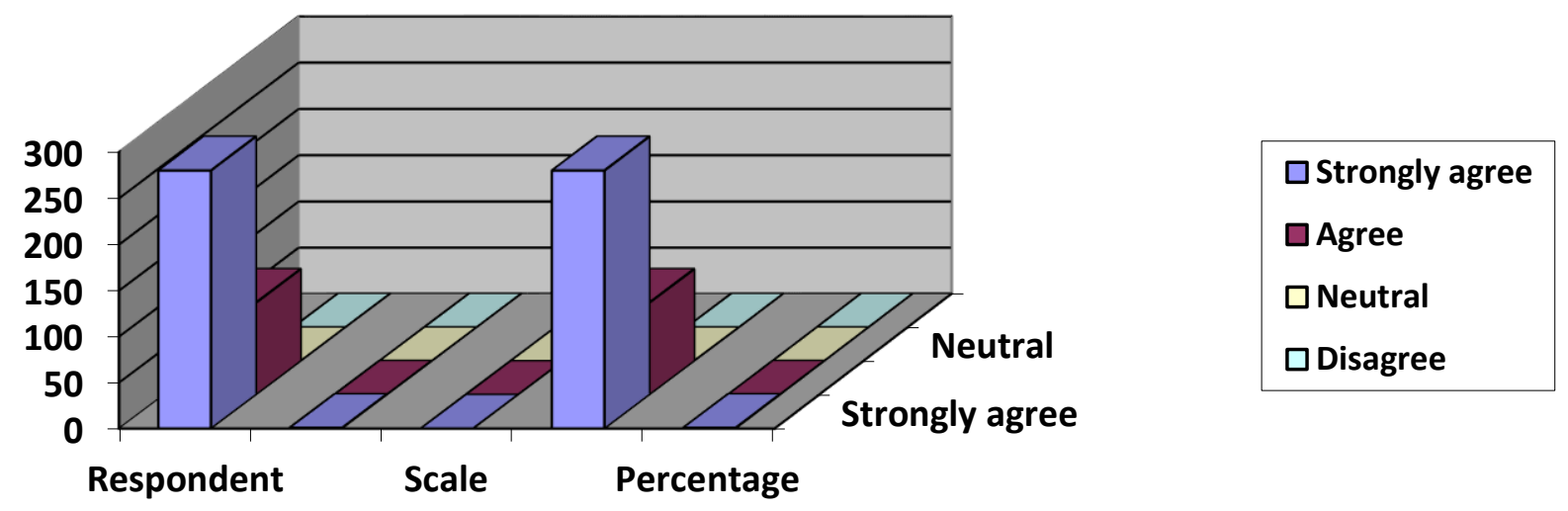

Table 6: School Rule and regulation affect students' academic performance

\begin{tabular}{|l|l|l|}
\hline Scale & Respondent & Percentage \\
\hline Strongly agree & 230 & $60.53 \%$ \\
\hline Agree & 144 & $37.89 \%$ \\
\hline Neutral & 6 & $1.58 \%$ \\
\hline Disagree & - & - \\
\hline $\begin{array}{l}\text { Strongly } \\
\text { Disagree }\end{array}$ & - & \\
\hline Total & $\mathbf{3 8 0}$ & $\mathbf{1 0 0 \%}$ \\
\hline
\end{tabular}

\section{Sources: Field survey2014}

Table 6 depict that 230 or $60.53 \%$ of the respondents strongly agree that rule and regulation affect students' academic performance; 144 or 37.89 agree while 6 or $1.58 \%$ were neutral. Hence, 
Vol. 3, No. 1, 2013, E-ISSN: $2226-6348$ @ 2013 HRMARS

majority of the students were in support that rule and regulation impact on the students' academic performance. See figure 6 below for a graphic picture of this result.

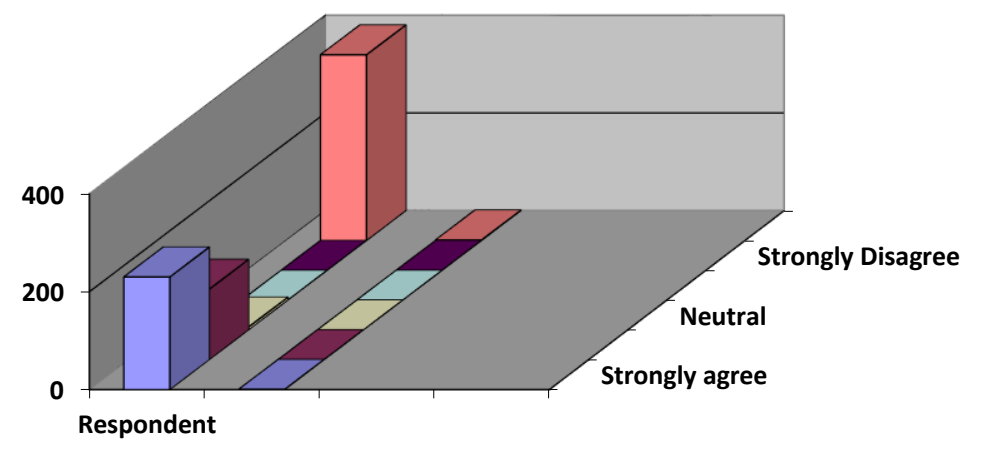

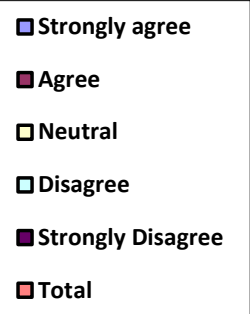

Table 7: The administrations of punishment in school improve students' academic performance

\begin{tabular}{|l|l|l|}
\hline Scale & Respondent & Percentage \\
\hline Strongly agree & 280 & $73.7 \%$ \\
\hline Agree & 74 & $19.5 \%$ \\
\hline Neutral & 6 & $1.6 \%$ \\
\hline Disagree & 12 & $3.2 \%$ \\
\hline $\begin{array}{l}\text { Strongly } \\
\text { Disagree }\end{array}$ & 8 & $2.1 \%$ \\
\hline Total & $\mathbf{3 8 0}$ & $\mathbf{1 0 0 \%}$ \\
\hline
\end{tabular}

Sources: Field survey2014

Table 7 indicates that 280 or $\mathbf{7 3 . 7 \%}$ of the respondents strongly agree that punishment in school improve students' academic performance; 74 or $19.5 \%$ agree; 12 or $3.2 \%$ disagree while 8 or $2.1 \%$ strongly disagree. Thus, the survey revealed that majority of the students' i:e about 354 or $93.2 \%$ were in support of punishments, thus improved academic performance. See figure 7 below for a graphic picture of this result.

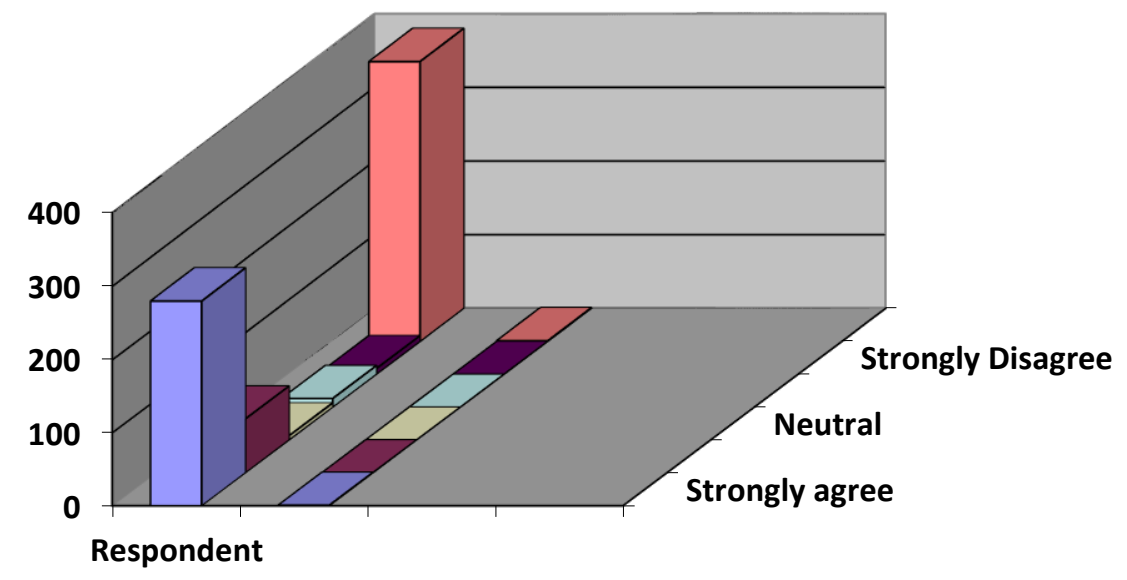

$\square$ Strongly agree
$\square$ Agree
$\square$ Neutral
$\square$ Disagree
$\square$ Strongly Disagree
$\square$ Total


INTERNATIONAL JOURNAL OF ACADEMIC RESEARCH IN PROGRESSIVE EDUCATION AND

DEVELOPMENT

Vol. 3, No. 1, 2013, E-ISSN: $2226-6348$ @ 2013 HRMARS

\section{Test of Hypothesis}

Chi-square $\left(x^{2}\right)$ statistical tool was used for testing the hypotheses of the survey work for the primary data collected. However, the formula for calculating Chi-square $\left(x^{2}\right)$ is stated below:

$\mathrm{X}^{2}=\sum \frac{(0-E)^{2}}{E}$

Where 0 is the observed frequency and $E$ is the expected frequency

\section{Hypothesis 1}

$H_{l}$ : $\quad$ Management of School Discipline Affect Students' Academic Performance.

$H_{0}$ : Management of school discipline does not affect student academic performance.

Table 8: Test of Hypothesis 1

\begin{tabular}{|l|l|l|l|l|l|}
\hline $\begin{array}{l}\text { Respondent } \\
\text { view }\end{array}$ & $\begin{array}{l}\text { Observed } \\
\mathbf{0}\end{array}$ & $\begin{array}{l}\text { Expected } \\
\text { E }\end{array}$ & $\begin{array}{l}\text { Residual } \\
\mathbf{0 - E}\end{array}$ & $\begin{array}{l}\text { (0-E) } \\
\mathbf{2}\end{array}$ & $\begin{array}{l}(\mathbf{0}-\mathrm{E})^{\mathbf{2}} \\
\mathbf{E}\end{array}$ \\
\hline $\begin{array}{l}\text { Strongly } \\
\text { agree }\end{array}$ & 220 & 76 & 124 & 15,376 & 202,316 \\
\hline Agree & 129 & 76 & 53 & 2,809 & 36,961 \\
\hline Neutral & 6 & 76 & -70 & 4,900 & 64,474 \\
\hline Disagree & 20 & 76 & -56 & 3,136 & 41,263 \\
\hline $\begin{array}{l}\text { Strongly } \\
\text { Disagree }\end{array}$ & 5 & 76 & -71 & 5,041 & 66,329 \\
\hline Total & 380 & 380 & & & 411,343 \\
\hline
\end{tabular}

Source: Computed from data, 2014

Therefore the calculated Chi-square $\left(x^{2}\right)=411,342$

Degree of freedom $(d f)=(r-1)(c-1)$

Hence, $\mathrm{df}=(5-1)(5-1)$

Therefore $\mathrm{df}=16$

Tabulated $\left(x^{2}\right)$ at $0.05 \%$ level of significance for 16 degree of freedom is 26.296 .

Decision: since the calculated Chi-square is greater than the tabulated, the alternative hypothesis $\left(\mathrm{H}_{\mathrm{i}}\right)$ is accepted and the null hypothesis $\left(\mathrm{H}_{\mathrm{o}}\right)$ is rejected. This indicates that management of school discipline affect student academic performance.

\section{Hypothesis 2}

Hi: The administration of punishment enhances academic performance.

Ho: The administration of punishment does not enhance students' academic performance. 
Table 9: Test of Hypothesis 1

\begin{tabular}{|c|c|c|c|c|c|}
\hline $\begin{array}{l}\text { Respondent } \\
\text { view }\end{array}$ & $\begin{array}{l}\text { Observed } \\
0\end{array}$ & $\begin{array}{l}\text { Expected } \\
\text { E }\end{array}$ & $\begin{array}{l}\text { Residual } \\
0-E\end{array}$ & $(0-E)^{2}$ & $\frac{(0-E)^{2}}{E}$ \\
\hline $\begin{array}{l}\text { Strongly } \\
\text { agree }\end{array}$ & 280 & 76 & 304 & 92,416 & 121,600 \\
\hline Agree & 74 & 76 & -2 & 4 & 53 \\
\hline Neutral & 6 & 76 & -70 & 4,900 & 64.474 \\
\hline Disagree & 12 & 76 & -64 & 4,096 & 53.895 \\
\hline $\begin{array}{l}\text { Strongly } \\
\text { Disagree }\end{array}$ & 8 & 76 & -68 & 4,624 & 60.842 \\
\hline Total & 380 & 380 & 100 & & 300.811 \\
\hline
\end{tabular}

Source: Computed from data, 2014

Therefore the calculated Chi-square $\left(x^{2}\right)=300.811$

Degree of freedom $(d f)=(r-1)(n-1)$

Hence, $\mathrm{df}=(5-1)(5-1)$

Therefore $\mathrm{df}=16$

Tabulated $\left(x^{2}\right)$ at $0.05 \%$ level of significance for 16 degree of freedom is 26.296 .

Decision: since the calculated Chi-square is greater than the tabulated, the alternative hypothesis $\left(\mathrm{H}_{\mathrm{i}}\right)$ is accepted and the null hypothesis $\left(\mathrm{H}_{\mathrm{o}}\right)$ is rejected. This indicates that administration of punishment in school enhance academic performance.

\section{Research Findings}

The analysis of the primary data in this study generated the following findings.

[1] That more than $70 \%$ of the respondents were of the opinion that management of school discipline has impact on the students' academic performance.

[2] Over $70 \%$ of the respondents strongly agreed that the observance of time management affect students' academic performance.

[3] Significant proportion of the respondents (60.53\%) strongly agree that rule and regulation affect students' academic performance

[4] However, $78.9 \%$ were not in support of punishments and does not improve academic performance.

\section{Conclusion}

The study dealt with the effects of discipline on students' academic performance in some secondary schools in Nigeria. On the whole, the study revealed that school rule and regulation play significant roles in enhancing students' academic performance. The adoption further revealed that when rule and regulation is emphasized, it in a long run prescribes the standard of behaviour expected of students and teachers.

It should be noted that a lot of activities take place in schools and much of these activities are to be guided by a structured school time table. In view of this, it is suggested that the school head teacher and the teachers should be very strict and respect the time allocated to some activities 
as indicated on the time table. This further portrait the fact that student have to adhered to the allocated time, knowing full well that there will be no time compensation for time lose thereby make the students' to be more serious and time conscious in their studies.

However, we must understand that punishment is a mean of bring about desirable change in students, if measurable and commensurate with the offence committed. There should be disciplinary committees that must be respected in terms of decision-making and be given powers and authority to execute their duties on any student regardless their background. We must also understand that students should be counsel but such counselling is to enable pupils the offence committed and why they should be punished. Though the role of guidance and counselling is to prevent the students from committing an offence but we must know that this cannot be realised in totality, therefore counsellor should not be made head of disciplinary committee. Nevertheless, the realisation of the above measures of punishment creates a proper decorum for teaching and learning to take place, thereby boast students' performance. Lastly, education with morality and vice versa is needed for national development.

\section{Acknowledgement}

My first gratitude goes to the almighty God for the breath and the strength all the time. Secondly, my appreciation goes to the various authors cited in the references and lastly, special thanks to the pupils and staff of various schools used as case study.

\section{Corresponding Author}

Ehiane O. Stanley

Lagos state Polytechnic, (SPTSA), Ikorodu, Mainland Annex, P O box 2090, Ikeja, Lagos, Nigeria Email: stanleyehiane@yahoo.com.

\section{References}

Adams, N. (2003). Secondary School Management Today._London, Melbourne, Sydney, Auckland Johannesburg, Hutchinson Ltd, Clandos place.

Adeyemo, P. A. (1985). Principles and Practice of Education: University of ile-Ife.

Amin, M. E. (2005). Social Science Research; Conception, Methodology and Analysis. Makerere University, Kampala.

Birkett V. (2004). How to Support and Manage Teaching Assistants, London, LDA.

Bratton, J., and Gold, J. (2003). Human Resource Management Theory and Practice._Bath Press, Great Britain.

Borkan, B., Cappa, Y., Figueiredo, C., Loadman, W. E. (2003) Using Research Measurement to Evaluate Organisational Climate Index, Paper Presented at The Annual Meeting of the MidWestern Educatiobal Research association, Columbus, $\mathrm{OH}$.

Baumard, P. (1999). Tacit Knowledge in Organizations, Sage, London.

Bean, A. (1999). Affect in The Curriculum: Towards Democracy, dignity and diversity. New York: Teachers College Press.

Brint, S., Cantwell, A. (2006). Undergraduate Time Use and Academic Outcomes: Results from University of California Undergraduate Experience Survey 2006. Center for Studies in Higher Education, 1-14. 
INTERNATIONAL JOURNAL OF ACADEMIC RESEARCH IN PROGRESSIVE EDUCATION AND

DEVELOPMENT

Vol. 3, No. 1, 2013, E-ISSN: $2226-6348$ @ 2013 HRMARS

Byarugaba, J. (1991). The Relationship Between Students" Participation in Decision-Making and Discipline in Secondary Schools in Kabale District. M. Ed. Thesis, Makerere University.

Chen, G. (2008). Communities, Students, Schools, and School Crime: A Confirmatory Study of Crime in U.S. High Schools. Urban Education, 43, 301-318.

Canter, L. (2000). Assertive Discipline in C. H. Edwards, ed., classroom discipline and management, 3rd Ed., John Wiley and Sons, MA, USA.

Creswell, J. W. (2003). Research Design: Qualitative, Quantitative and Mixed Method Approaches. Sage Publications, United Kingdom.

Docking, J. W. (2000). Control and Discipline in Schools. London, Harper and Row publishers.

Durand, V. M. (1990). Severe Behavioural Problems in The Classroom. NewYork: Guildford Press Dunham, V. (1984). Stress in Teaching. London, Croom Helm.

Everard, K. B., \& Morris, G. (1996). Effective School Management. London: Paul Chapman Publishers.

Eilam, B., And Aharon, I. (2003), 'Students Planning in The Process of Self-Regulated Learning' Contemporary Educational Psychology. Vol 28. PP30-34

Gawe, N., Jacobs, M., Vakalisa, N. (2001). Teaching and Learning Dynamics: A Participative Approach . Johannesburg: Heinemann

Hernandez, T. J., and Seem, S. R. (2004). A Safe School Climate: A Systemic Approach and the School Counselor. ASCA, Professional School Counseling, Vol 7 (4), 256-262

Kajubi, S. W. (1997). Discipline Corporal Punishment and Violence Against Children in the School System. Keynote Address; Public Lecture, 13th June 1997, Makerere University.

Kabandize, L. I. (2004). The Management of Students" Discipline in Secondary Schools. Heinemann

Byarugaba, J. (1991). The Relationship Between Students" Participation in Decision-Making and Discipline in Secondary Schools in Kabale District. M. Ed. Thesis, Makerere University.

Kelly, W. E. (2004). As Achievement Sails the River of Time: The Role of Time Use Efficiency in Grade-Point-Average. Educational Research Quarterly, Vol. 27 No.4, 3-8.

Matsoga, J. T. (2003). Crime and School Violence in Botswana Secondary Education: The Case of Moeding Senior Secondary School, PhD Dissertation. Ohio University.

Nichols, J. D. (2004). An Exploration of The Discipline and Suspension Data. Journal of Negro Education, 73(4), 408-423.

Okumbe, J. A. (1998). Educational Management Theory and Practices: Nairobi University Press.

Sonn, B. (1999). Discipline in Schools: Discipline in Culture Human Rights. Cape Town: Via Africa

Schoonover, B. (2009). Zero Tolerance Discipline Policies: The History, Implementation, and Controversy of Zero Tolerance Policies in Student Codes Of Conduct. New York, NY: Universe, Inc

Verdugo, R., \& Glenn, B. (2002). Race-Ethnicity, Class and Zero Tolerance Policies: A Policy of Discussion. Presented at the American Education Research Association

Convention, New Orleans.

Visser, P. (1999). Some Thoughts on Corporal Punishment and Lawful Use of Force At School. Vol 62: 435.

Wood, C., Nicholson, E. W., \& Findley, D. S. (1985). The Secondary School Principal: Manager and Supervisor. Newton: Allyn \& Bacon. 
INTERNATIONAL JOURNAL OF ACADEMIC RESEARCH IN PROGRESSIVE EDUCATION AND

DEVELOPMENT

Vol. 3, No. 1, 2013, E-ISSN: 2226-6348 @ 2013 HRMARS

Willsi, J. F., \& William, K. (1982). Principles of Effective Discipline. Boston: Allyn \& Bacon. 